doi: 10.2306/scienceasia1513-1874.2013.39.236

\title{
Characterization of mannanase S1 from Klebsiella oxytoca KUB-CW2-3 and its application in copra mannan hydrolysis
}

\author{
Sudathip Titapoka Chantorn ${ }^{\mathrm{a}}$, Nawapan Pongsapipatana ${ }^{\mathrm{b}}$, Suttipan Keawsompong ${ }^{\mathrm{b}}$, \\ Arunee Ingkakul $^{\mathrm{c}}$, Dietmar Haltrich ${ }^{\mathrm{d}}$, Sunee Nitisinprasert ${ }^{\mathrm{b}, *}$ \\ a Department of Biotechnology, Faculty of Science and Technology, Thammasat University, Rangsit Campus, \\ Pathumthani, Thailand \\ b Department of Biotechnology, Faculty of Agro-Industry, Kasetsart University, Bangkok, Thailand \\ c Department of Biochemistry, Faculty of Science, Kasetsart University, Bangkok, Thailand \\ d Department of Food Science and Technology, Food Biotechnology Laboratory, \\ BOKU University of Natural Resources and Life Sciences, Vienna, Austria
}

*Corresponding author, e-mail: fagisnn@ku.ac.th

Received 15 May 2012

Accepted 22 Mar 2013

\begin{abstract}
The mannanase S1 from Klebsiella oxytoca KUB-CW2-3 was purified by a single anion exchange chromatography to electrophoretic homogeneity. S1 is a protein with a molecular mass of approximately $165 \mathrm{kDa}$ and a $\mathrm{pI}$ value of 3.5. The optimum $\mathrm{pH}$ and temperature of mannanase activity were 4.0 and $40{ }^{\circ} \mathrm{C}$, respectively. The enzyme exhibited good stability over the broad $\mathrm{pH}$ range of 3-6. The mannanase S1 exhibited specific activity for different mannan substrates including galactomannan from locust bean gum (LBG), copra meal, and glucomannan from konjac, while neither xylanase nor cellulase activity were detectable. The Michaelis-Menten constants $\left(K_{\mathrm{m}}\right)$, maximum velocity $\left(V_{\max }\right)$, and the catalytic constant $\left(k_{\text {cat }}\right)$ values of S1 against LBG and konjac mannan were 1.038-1.056 mg/ml, 6.149$6.183 \mu \mathrm{U} \mathrm{ml}^{-1} \mathrm{~min}^{-1}$, and $0.047 \mathrm{~s}^{-1}$, respectively. In addition, mannanase activity was activated by $\mathrm{Co}^{2+}(129 \%)$ but completely inhibited by EDTA and $\mathrm{Zn}^{2+}$. The $\mathrm{N}$-terminal amino acid sequence (GRVGEAGPHGPHGPH) of mannanase S1 is different from the N-terminal region of other bacterial mannanases belonging to the glycoside hydrolase family GH5. The degradation products of mannanase S1 from LBG hydrolysis were galactose and unknown oligosaccharides with a different molecular structure to mannobiose, triose, and tetraose indicating the cleavages of $\alpha$-1,6-galactosidic and $\beta$-1,4-mannosidic linkages. Its hydrolysis of $100 \mathrm{mM} \mathrm{CoCl}_{2}$-treated copra mannan enhanced the growth of Lactobacillus reuteri KUB-AC5 but inhibited that of Salmonella serovar Enteritidis S003, indicating potential prebiotic properties by the action of mannanase from $K$. oxytoca.
\end{abstract}

KEYWORDS: $\beta$-mannanase, copra meal, prebiotics

\section{INTRODUCTION}

Copra meal, a cheap agricultural by-product from the coconut industry in tropical areas, has recently gained significant attraction for the production of prebiotic manno-oligosaccharides ${ }^{1-4}$. Copra meal typically consists of $65 \%$ galactomannan, $5 \%$ lignin, $21 \%$ protein, and nearly $10 \%$ fat $^{5,6}$. The abundance of heterogalactomannan found in this agricultural by-product can be conveniently used to produce manno-oligosaccharides (together with small amounts of mannose and galactose) by employing mannan endo-1,4$\beta$-mannosidase, 1,4- $\beta$-D-mannanase (EC 3.2.1.78), or commonly named $\beta$-mannanase ${ }^{7-9}$. These mannan endo- $1,4-\beta$-mannosidases produced by various species of bacteria, fungi, plants, and invertebrates have also a number of other applications in different sectors of food, feed, pharmaceutical, and pulp/paper industries $^{8}$.

Klebsiella oxytoca KUB-CW2-3 was isolated from fermented coconut waste and was shown to actively hydrolyse both locust bean gum and copra mannan ${ }^{10}$. Its $\beta$-mannanase yields were lower than those reported for some other bacterial and fungal sources ${ }^{11-13}$. However, copra hydrolysates produced by $K$. oxytoca KUB-CW2-3 clearly showed growth promoting properties for Lactobacillus reuteri but growth inhibitory effects for Salmonella Enteritidis growth, indicating valuable prebiotic properties of this copra hydrolysates ${ }^{10}$. So far, there has not been 
report on the property of the native enzyme and the action of mannan endo-1,4- $\beta$-mannosidase from $K$. oxytoca KUB-CW2-3. In this study, purification of the $\beta$-mannanase by chromatography and its subsequently characterization is shown. The hydrolytic activity of purified $\beta$-mannanase, and its degradation products together with potentially prebiotic properties are also presented.

\section{MATERIALS AND METHODS}

\section{Chemicals}

Locust bean gum (LBG; a galactomannan from Ceratonia siliqua), $\alpha$-mannan from Saccharomyces cerevisiae, and xylan from oat spelts were obtained from Sigma (St. Louis, MO, USA). Ivory nut mannan (a $\beta$-mannan from Phytelephas macrocarpa), konjac mannan (a glucomannan from Amorphophallus konjac), mannobiose, mannotriose, mannotetraose, mannoheptaose, and mannose-7-butyrate were purchased from Megazyme (Bray, Ireland). Carboxymethylcellulose (CMC) and Avicel cellulose were obtained from BDH Laboratory (Poole, England) and Merck (Darmstadt, Germany), respectively. Glucose, maltose, galactose, and mannose were purchased from Fluka (Buchs, Switzerland). All other chemicals were analytical grade.

\section{Preparation of copra meal}

The residual coconut cake bought from Pakkret Market (Nonthaburi, Thailand) was dried at $60^{\circ} \mathrm{C}$ for $4 \mathrm{~h}$, blended, and milled by a hammer mill (Janke \& Kunkel IKA Labortechnik) to obtain a particle size of $0.5 \mathrm{~mm}$. This preparation is designated as copra meal (CM). It was used as a substrate both for enzyme production and the determination of enzyme activity.

\section{Microorganisms and culture condition}

$K$. oxytoca KUB-CW2-3 ${ }^{10}$ was cultivated in nutrient broth (NB; Pronadisa, Madrid, Spain) at $37^{\circ} \mathrm{C}$ for $12-15 \mathrm{~h}$ with shaking at $150 \mathrm{rpm}$. L. reuteri KUBAC5, Escherichia coli E010, and Salmonella serovar Enteritidis S003 obtained from chicken intestine ${ }^{14}$ were used as target strains to determine prebiotic properties of the oligosaccharide preparations. They all were kept at the culture collection of the Department of Biotechnology, Kasetsart University, Thailand. L. reuteri KUB-AC5 was grown in de Man Rogosa Sharpe (MRS) broth (Merck) at $37^{\circ} \mathrm{C}$ for 12-15 h, while E. coli E010 and S. Enteritidis S003 were cultivated in NB under the same conditions with shaking at $150 \mathrm{rpm}$.

\section{Crude enzyme preparation}

One millilitre of a preculture of $K$. oxytoca KUBCW2-3, grown in $20 \mathrm{ml} \mathrm{NB}$ medium in a 100-ml Erlenmeyer flask with shaking at $150 \mathrm{rpm}$ under condition mentioned elsewhere ${ }^{10}$, was transferred into $100 \mathrm{ml}$ of enzyme production medium by modified from Mohammad et al ${ }^{15}$ consisting of $1 \%$ copra meal, $2 \% \mathrm{KH}_{2} \mathrm{PO}_{4}, 3 \%$ polypeptone, $0.06 \% \mathrm{MgSO}_{4}$, and $2 \%$ corn steep liquor in a $250-\mathrm{ml}$ Erlenmeyer flask. After $24 \mathrm{~h}$ incubation at $37^{\circ} \mathrm{C}$, cells were removed by centrifugation at $4{ }^{\circ} \mathrm{C}, 10000 \mathrm{~g}$ for $20 \mathrm{~min}$. The supernatant was collected and stored at $-20^{\circ} \mathrm{C}$ for further studies.

\section{Determination of mannanase activity}

Mannanase activity was determined by mixing $0.5 \mathrm{ml}$ of $0.5 \%$ copra meal in $50 \mathrm{mM} \mathrm{K} \mathrm{PO}_{4}$ buffer $\mathrm{pH} 7.0$ with $0.5 \mathrm{ml}$ of appropriately diluted enzyme sample for $30 \mathrm{~min}$ at $50{ }^{\circ} \mathrm{C}$ otherwise mentioned elsewhere. The reducing sugars released were measured by the dinitrosalicylic acid method ${ }^{16}$ against a standard curve of mannose. One unit of enzyme activity was defined as the amount of enzyme that gave rise to reducing sugar end groups corresponding to $1 \mu \mathrm{mol}$ of mannose per minute under the selected experimental conditions.

\section{Protein determination}

Protein concentration was determined by the method of Lowry et $\mathrm{al}^{17}$. Bovine serum albumin was used as a protein standard. All chromatographic runs were monitored by measuring the absorbance at $280 \mathrm{~nm}$.

\section{Purification procedure}

All purification steps were carried out at room temperature using an AKTA FPLC chromatographic system (GE Healthcare, Uppsala, Sweden). Starting from $1000 \mathrm{ml}$ of crude culture supernatant, mannanase was purified by adding ammonium sulphate to $70 \%$ saturation, collecting the precipitate by centrifugation at $4{ }^{\circ} \mathrm{C}, 7000 \mathrm{~g}$ for $30 \mathrm{~min}$, dissolving this precipitate in $100 \mathrm{ml}$ of $10 \mathrm{mM}$ bis-Tris buffer $\mathrm{pH} 7.0$, and dialysis against the same buffer. The dialysed enzyme solution (2 $\mathrm{ml})$ was applied to a Q Sepharose column $(1.6 \times$ $20 \mathrm{~cm}$; GE Healthcare) preequilibrated with $10 \mathrm{mM}$ bis-Tris buffer, $\mathrm{pH}$ 7.0. Bound protein was eluted with a linear gradient of $\mathrm{NaCl}(0-1 \mathrm{M})$ at a constant flow rate of $2 \mathrm{ml} / \mathrm{min}$ and active fractions were collected, pooled, and concentrated approximately 10-fold by ultrafiltration using a 10000 -Da molecular-weightcutoff membrane on a $180-\mathrm{ml}$ stirring cell (Amicon, Beverly, Mass). This preparation was then reloaded 
to the same column and repurified by performing the identical procedure.

\section{Electrophoresis}

Molecular mass of the purified enzyme was determined by SDS-PAGE according to Laemmli ${ }^{18}$ using a $10 \%$ acrylamide separating gel and staining with the silver stain plus kit (Bio-Rad, USA). Isoelectric focusing was performed on Ampholine PAGplate $\mathrm{pH}$ 3.59.5 (GE Healthcare) according to the instruction of the manufacturer. The isoelectric point was evaluated by staining with the silver stain plus kit and comparison with the broad range pI calibration kit (GE Healthcare).

\section{Effect of the $\mathrm{pH}$ value on activity and stability}

The optimum $\mathrm{pH}$ of mannanase activity was examined at $\mathrm{pH}$ values of 3.0-10.0 under otherwise standard assay conditions. An LBG solution $(0.5 \%$, w/v) in the appropriate buffers, each at $10 \mathrm{mM}$-citrate (pH 3.0-6.0), phosphate ( $\mathrm{pH}$ 6.0-8.0), and glycine$\mathrm{NaOH}$ ( $\mathrm{pH} 8.0-10.0$ ) — was used to determine mannanase activity at $50^{\circ} \mathrm{C}$ for $30 \mathrm{~min}$. Enzyme stability was determined using the same buffer systems in the range of 3.0-10.0 by incubating an enzyme solution in the various buffer solutions at $4{ }^{\circ} \mathrm{C}$ for $24 \mathrm{~h}$. Then, the remaining enzyme activity was measured under standard assay conditions.

\section{Effect of the temperature on activity and stability}

The temperature optimum of mannanase activity was determined by performing the standard activity assay at temperatures ranging from $30-60^{\circ} \mathrm{C}$ in $10 \mathrm{mM}$ buffer at $\mathrm{pH} 4.0$ for $30 \mathrm{~min}$. For the determination of thermal stability, an enzyme solution was incubated in $10 \mathrm{mM}$ buffer at $\mathrm{pH} 4.0$ and at various temperatures for $30 \mathrm{~min}$. Thereafter, the remaining enzyme activity was measured.

\section{Effect of various metal ions and chemicals on mannanases}

The effects of EDTA and mercaptoethanol as well as various metal ions $\left(\mathrm{Li}^{+}, \mathrm{Ca}^{2+}, \mathrm{Cu}^{2+}, \mathrm{Fe}^{2+}, \mathrm{Mg}^{2+}\right.$, $\mathrm{Mn}^{2+}, \mathrm{Zn}^{2+}, \mathrm{Ni}^{2+}$, and $\mathrm{Co}^{2+}$ ), each at a concentration of $1 \mathrm{mM}$, on mannanase activity were determined under standard assay conditions.

\section{Determination of kinetic parameters}

The Michaelis-Menten kinetic parameters, $K_{\mathrm{m}}, V_{\max }$, and $k_{\text {cat }}$ were determined by using LBG and konjac mannan as substrates. These reactions were performed at $50{ }^{\circ} \mathrm{C}$ and $\mathrm{pH} 4.0$ with various substrate concentrations ranging from $0.1-1 \%(\mathrm{w} / \mathrm{v})$. Samples were taken every $5 \mathrm{~min}$ for a total of $30 \mathrm{~min}$ and only the linear part of the reaction curve was used for the determination of activity. The $K_{\mathrm{m}}$ and $V_{\max }$ were calculated from Lineweaver-Burk plots.

\section{Determination of substrate specificity}

Various substrates including locust bean galactomannan, yeast $\alpha$-mannan, ivory nut mannan, konjac glucomannan, xylan (from oat spelts), carboxymethylcellulose (CMC), avicel, and copra meal, each at a concentration of $0.5 \%(\mathrm{w} / \mathrm{v})$, were used for the determination of mannanase activity under standard assay conditions.

\section{Determination of amino acid sequence}

The N-terminal amino acid sequence of the purified mannanase was determined by Edman degradation at Research and Research Training Services, University of Newcastle, Australia. Sequence homology was analysed by using the BLAST database.

\section{Hydrolysis experiments}

The purified mannanase $(0.05 \mathrm{U} / \mathrm{ml})$ was incubated with $0.5 \%(\mathrm{w} / \mathrm{v})$ LBG in $10 \mathrm{mM}$ citrate buffer $\mathrm{pH}$ 4.0. The reaction mixture was incubated at $40^{\circ} \mathrm{C}$ for $4 \mathrm{~h}$. Aliquots were removed at $1 \mathrm{~h}$ intervals, and the reaction was stopped by heating at $70{ }^{\circ} \mathrm{C}$ for $10 \mathrm{~min}$. The hydrolysates were analysed by thin-layer chromatography (TLC) according to a modified method of Sachslehner et al ${ }^{19}$. The solvent used as mobile phase was composed of butanol:isopropanol:ethanol:deionized water in the ratio of 2:3:3:2, respectively. Two microlitres of sample was applied onto Kieselgel 60 plates (Merck) and developed for $90 \mathrm{~min}$ in developing solvent. The TLC plates were then developed by dipping in $0.2 \%(\mathrm{w} / \mathrm{v})$ orcinol in $10 \%$ (v/v) $\mathrm{H}_{2} \mathrm{SO}_{4}$ in ethanol at $100{ }^{\circ} \mathrm{C}$ for $15 \mathrm{~min}$, and sugars appeared as brown spots.

\section{Evaluation of prebiotic properties}

The copra meal hydrolysate (CM-hydrolysate) obtained by mannanase S1 treatment was used to determine potential prebiotic properties according to the method of Titapoka et $\mathrm{al}^{10}$. L. reuteri KUB-AC5, $S$. Enteritidis S003, and E. coli E010 were used as the target strains to determine possible growth effects of CM-hydrolysate. Briefly, each culture solution of the target strains was adjusted to absorbance of 0.5 at $600 \mathrm{~nm}$. Culture solution of each target strain (1\%) and $1 \%$ of the CM-hydrolysate or enzyme reaction buffer (control) were transferred into $5 \mathrm{ml}$ of MRS medium for $L$. reuteri and NB medium for $S$. Enteritidis and E. coli. The mixture was incubated at $37^{\circ} \mathrm{C}$ 
Table 1 Purification of mannanase from $K$. oxytoca KUB-CW2-3.

\begin{tabular}{lccccrr}
\hline Steps & $\begin{array}{c}\text { Total volume } \\
(\mathrm{ml})\end{array}$ & $\begin{array}{c}\text { Total activity } \\
(\text { Units })\end{array}$ & $\begin{array}{c}\text { Total protein } \\
(\mathrm{mg})\end{array}$ & $\begin{array}{c}\text { Sp. activity } \\
(\text { U/mg protein })\end{array}$ & $\begin{array}{c}\text { Purification } \\
\text { fold }\end{array}$ & $\begin{array}{c}\text { Yield } \\
(\%)\end{array}$ \\
\hline Crude & 1000 & 515 & 1962 & 0.26 & 1 & 100.00 \\
Precipitate + dialysis & 100 & 44.3 & 288.4 & 0.15 & 0.58 & 8.60 \\
Q Sepharose I + UF & 20 & 7.8 & 0.92 & 8.48 & 32.62 & 1.51 \\
Q Sepharose II + UF & 20 & 4 & 0.12 & 33.33 & 128.19 & 0.77 \\
\hline
\end{tabular}

for $4 \mathrm{~h}$ and then cell number was determined by the standard plate count assay overnight at $37^{\circ} \mathrm{C}$ using either MRS or NB medium containing $2 \%$ agar. The prebiotic properties of CM-hydrolysate were defined as an enhancing activity of $L$. reuteri growth and inhibitory activity of $S$. Enteritidis and $E$. coli growth according to the following equations:

$$
\begin{aligned}
& \text { Enhancing activity }=\mathrm{SF}-\mathrm{CF}, \\
& \text { Inhibition activity }=\mathrm{CF}-\mathrm{SF},
\end{aligned}
$$

where $\mathrm{SF}$ and $\mathrm{CF}$ were the cell number obtained in the growth experiments containing CM-hydrolysate and the cell number in control experiments, respectively $(\log \mathrm{cfu} / \mathrm{ml})$.

\section{RESULTS}

\section{Purification of mannanase}

One litre of culture supernatant containing mannanase activity was purified by ammonium sulphate precipitation and anion exchange chromatography. Twenty millilitres of the active fraction after $70 \%$ ammonium sulphate precipitation were dialysed and subsequently loaded onto a Q Sepharose column twice in succession to obtain a single peak of activity with the purification efficiency and yield of 128 -fold and $0.77 \%$, respectively. The final mannanase preparation thus obtained was electrophoretically homogeneous as judged by SDS-PAGE and was designated as mannanase S1. The results of the purification are summarized in Table 1. The molecular mass and $\mathrm{pI}$ value of mannanase S1 were $165 \mathrm{kDa}$ and 3.5, respectively (Fig. 1).

\section{Effects of pH and temperature on mannanase S1}

The optimum $\mathrm{pH}$ of mannanase $\mathrm{S} 1$ activity was shown to be at $\mathrm{pH} 4.0$ (Fig. 2a). The enzyme was stable over a broad $\mathrm{pH}$ range of 3-6, retaining more than $60 \%$ of its activity when incubating the enzyme at the respective $\mathrm{pH}$ and $4{ }^{\circ} \mathrm{C}$ for $24 \mathrm{~h}$, while the activity rapidly decreased at $\mathrm{pH} 7.0$ and 8.0 (Fig. 2a) and completely lost at $\mathrm{pH} 9.0$ under these conditions.

The optimum temperature of mannanase $\mathrm{S} 1$ was at $40^{\circ} \mathrm{C}$ for standard assay conditions (Fig. 2b). The
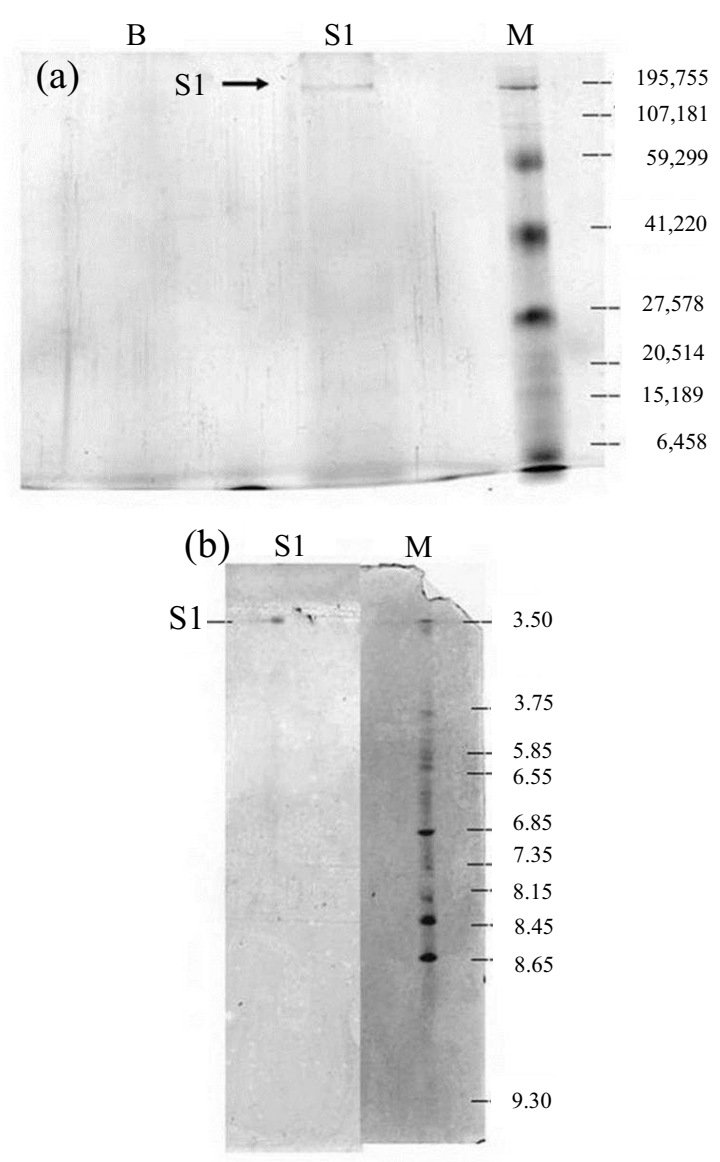

Fig. 1 Electrophoretic analysis of purified S1. (a) SDSPAGE of purified S1: lane B, sample buffer; lane S1, purified S1; lane M, prestained marker (Bio-Rad). (b) Isoelectric focusing electrophoresis: lane $\mathrm{S} 1$, purified $\mathrm{S} 1$; lane $\mathrm{M}$, broad pI calibration kit (Amersham).

half-life times of stabilities of mannanase $\mathrm{S} 1$ at 40, 50, 60 , and $70^{\circ} \mathrm{C}$ were $4,3,3$, and $1 \mathrm{~h}$, respectively.

\section{Effect of chemicals}

The effects of various metal ions and chemical reagents on mannanase activity are shown in Table 2. Mannanase activities is completely inhibited by EDTA and $\mathrm{Zn}^{2+}$. The enzyme showed strong inhibi- 

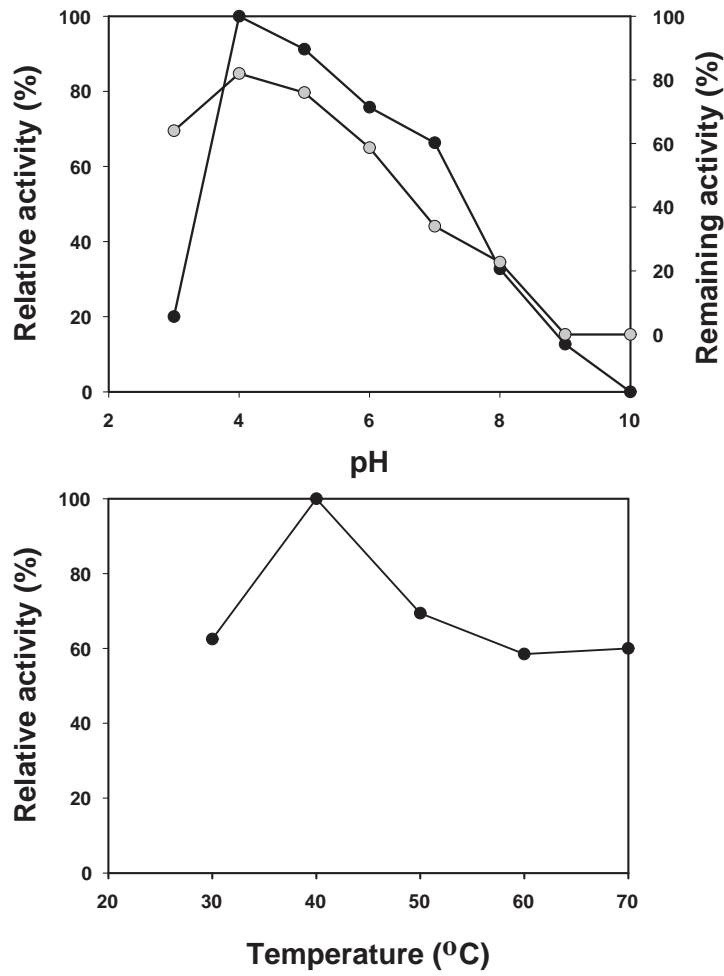

Fig. 2 Effects of (a) $\mathrm{pH}$ and (b) temperature on the activity of mannanase S1 from $K$. oxytoca KUB-CW2-3. Black circles: relative activity; grey circles: remaining activity.

Table 2 Effect of various salts/metal ions and other chemical compounds (each at a concentration of $1 \mathrm{mM}$ ) on the activity of mannanase S1 from $K$. oxytoca KUB-CW2-3.

\begin{tabular}{lc}
\hline Ion & Relative activity $(\%)$ \\
\hline Control & 100 \\
EDTA & 0 \\
$\mathrm{ZnSO}_{4}$ & 0 \\
$\mathrm{CaCl}_{2}$ & 13 \\
$\mathrm{CuSO}_{4}$ & 16 \\
$\mathrm{FeSO}_{4}$ & 16 \\
$\mathrm{MnSO}_{4}$ & 23 \\
$\mathrm{NiSO}_{4}$ & 32 \\
$\mathrm{MgSO}_{4}$ & 36 \\
$\mathrm{LiCl}$ & 45 \\
$\mathrm{Mercaptoethanol}_{\mathrm{CoCl}}$ & 84 \\
\hline
\end{tabular}

tion of more than $70 \%$ by $\mathrm{Ca}^{2+}, \mathrm{Cu}^{2+}, \mathrm{Fe}^{2+}, \mathrm{Mn}^{2+}$ when present at $1 \mathrm{mM}$. Mannanase activity was, however, activated by $\mathrm{Co}^{2+}$ with the highest activity of $0.055 \mathrm{U} / \mathrm{ml}$ observed at $100 \mathrm{mM} \mathrm{Co}^{2+}$ ion.
Table 3 Substrate specificity of mannanase S1 from K. oxytoca KUB-CW2-3 towards various polysaccharide substrates.

\begin{tabular}{lc}
\hline Substrate & Relative activity (\%) \\
\hline Locust bean gum (galactomannan) & 100 \\
Ivory nut mannan (mannan) & 60 \\
Konjak glucomannan (glucomannan) & 54 \\
Alpha-mannan (yeast) & $<1$ \\
Xylan (from oat spelts) & $<1$ \\
Carboxymethylcellulose & $<1$ \\
Avicel & $<1$ \\
Copra meal & 20 \\
\hline
\end{tabular}

\section{Substrate specificity}

Table 3 shows the relative activities of mannanase S1 for various polysaccharide substrates. Mannanase S1 exhibited the highest activity against LBG, which is taken as $100 \%$ relative activity. It also hydrolysed ivory nut mannan, konjac glucomannan, and copra meal with lower relative activities of 60,54 , and $20 \%$, respectively. On the other hand, no hydrolytic activity against yeast $\alpha$-mannan, xylan (from oat spelts), $\mathrm{CMC}$, and avicel was observed.

\section{Kinetic properties of mannanase S1}

The $K_{\mathrm{m}}, V_{\mathrm{max}}$, and $k_{\mathrm{cat}}$ values of mannanase $\mathrm{S} 1$ for its substrate locust bean gum galactomannan were determined to be $1.06 \mathrm{mg} / \mathrm{ml}, 6.15 \mu \mathrm{U} \mathrm{ml}^{-1} \mathrm{~min}^{-1}$, and $0.047 \mathrm{~s}^{-1}$, respectively, while the ones on konjac glucomannan were $1.038 \mathrm{mg} / \mathrm{ml}, 6.183 \mu \mathrm{U} \mathrm{ml}^{-1} \mathrm{~min}^{-1}$, and $0.047 \mathrm{~s}^{-1}$, respectively. This could be concluded that the kinetic values for LBG and konjac mannan were nearly identical.

\section{Amino acid sequence}

The sequence of $15 \mathrm{~N}$-terminal amino acids obtained was "GRVGEAGPHGPHGPH". This showed no matching with the N-terminal region of any bacterial mannanase by Protein-Protein BLAST (blastp) analysis (http://www.ncbi.nlm.nih.gov).

\section{Degradation pattern}

Both copra mannan and LBG are galactomannans. However, the activity of mannanase S1 against copra mannan is lower than against LBG as concluded from the previous results. Hence LBG was selected as a substrate for further experiments, in which the hydrolysis of galactomannan by mannanase $\mathrm{S} 1$ and the corresponding hydrolysis products were studied. Samples of LBG degradation by mannanase S1 were taken at $0,1,2,3$, and $4 \mathrm{~h}$ and analysed for the 


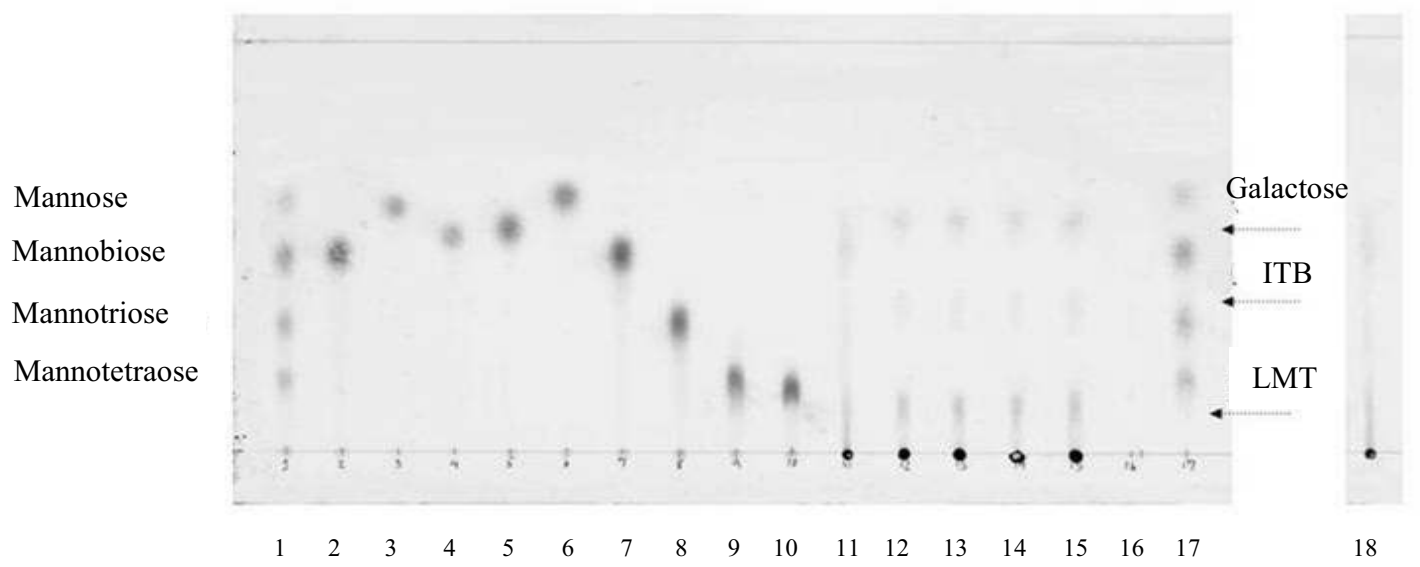

Fig. 3 Locust bean gum hydrolysis by mannanase S1 from $K$. oxytoca KUB-CW2-3 after reaction times of 0, 1, 2, 3, and 4 h. Lane 1: mannooligosaccharide standard. Lane 2: mannose-7-butyrate. Lane 3: glucose. Lane 4: maltose. Lane 5: galactose. Lane 6: mannose. Lane 7: mannobiose. Lane 8: mannotriose. Lane 9: mannotetraose. Lane 10: mannoheptaose. Lane 11: $0 \mathrm{~h}$. Lane 12: $1 \mathrm{~h}$. Lane 13: $2 \mathrm{~h}$. Lane 14: $3 \mathrm{~h}$. Lane 15: $4 \mathrm{~h}$ of reaction time. Lane 16: $\mathrm{S} 1$ mannanase preparation. Lane 17: standard mannooligosaccharides. Lane 18: locust bean gum.

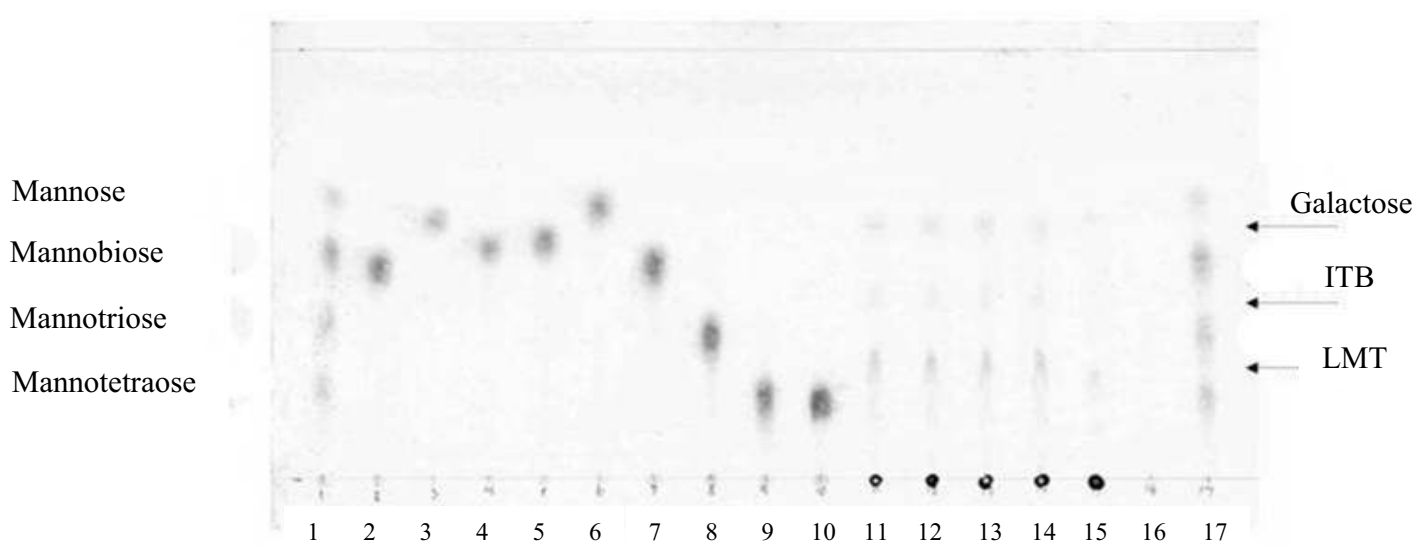

Fig. 4 Locust bean gum degradation by $\mathrm{S} 1$ with $100 \mathrm{mM} \mathrm{CoCl}$ at various times of $0,1,2$, 3, and 4 h. Lane 1: standard mannooligosaccharides. Lane 2: mannose-7-butyrate, Lane 3: Glucose. Lane 4: Maltose. Lane 5: galactose. Lane 6: mannose. Lane 7: mannobiose. Lane 8: mannotriose. Lane 9: mannotetraose. Lane 10: mannoheptaose. Lane 11: 0 h. Lane 12: 1 h. Lane 13: 2 h. Lane 14: 3 h. Lane 15: 4 h of reaction time. Lane 16: S1 mannanase preparation. Lane 17: standard mannooligosaccharides.

oligomeric reaction products by thin layer chromatography. Glucose, galactose, maltose, mannose, mannobiose, mannotriose, mannotetraose, mannoheptaose, and mannose-7-butyrate were used as standard markers (Fig. 3). For the reaction with purified mannanase $\mathrm{S} 1$, the three main products that were identified during the hydrolysis reaction were galactose, an unknown compound having an intermediate $R_{\mathrm{f}}$ between mannotriose and mannobiose, designated as ITB, and unknown molecules larger than mannotetraose, designated as LMT (Fig. 3). Both galactose and ITB were still detected as shown in Fig. 4 when $100 \mathrm{mM} \mathrm{CoCl}_{2}$ was added in the hydrolysis reaction as an effector of mannanase activity. However, a new compound with $R_{\mathrm{f}}$ between mannotriose and mannotetraose, designated as ITT, appeared. Interestingly, no unsubstituted mannooligosaccharides such as mannobiose or mannotriose could be detected by TLC. The unidentified oligosaccharides ITB and ITT could be mannooligosaccharides substituted with galactosyl side chains. 


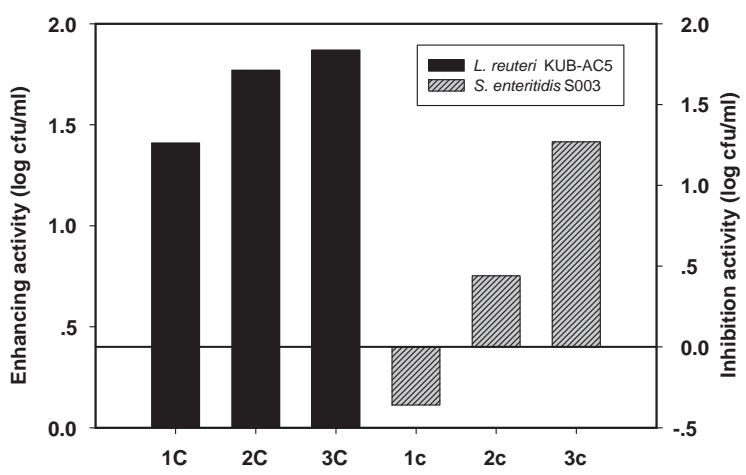

Fig. 5 Effects of Co-CM-hydrolysate on enhancing activity of $L$. reuteri KUB-AC5 and inhibition activity of Salmonella serovar Enteritidis S003.

Table 4 Effect of Co-CM-hydrolysate on growth of L. reuteri KUB-AC5 and Salmonella serovar Enteritidis S003.

\begin{tabular}{lcc}
\hline Treatment & \multicolumn{2}{c}{ Survival cell $(\log \mathrm{cfu} / \mathrm{ml})$} \\
\cline { 2 - 3 } & KUB-AC5 & S003 \\
\hline Control & $8.20^{\mathrm{c}}$ & $12.39^{\mathrm{b}}$ \\
$0.31 \mathrm{mg} / \mathrm{ml}, 1 \mathrm{c}$ & $9.61^{\mathrm{b}}$ & $12.75^{\mathrm{a}}$ \\
$0.62 \mathrm{mg} / \mathrm{ml}, 2 \mathrm{c}$ & $9.97^{\mathrm{a}}$ & $11.95^{\mathrm{c}}$ \\
$0.93 \mathrm{mg} / \mathrm{ml}, 3 \mathrm{c}$ & $10.07^{\mathrm{a}}$ & $11.12^{\mathrm{d}}$ \\
\hline
\end{tabular}

Different letters in a column indicate statistical difference with $p<0.05$.

\section{Prebiotic properties}

This hydryolysis was then tested for potential prebiotic properties, i.e., its effect on growth of $L$. reuteri KUB-AC5 as a positive probiotic strain, as well as on growth of $S$. Enteritidis S003 and E. coli E010 as examples of potentially pathogenic/undesirable strains. The hydrolysis product obtained from a hydryolysis reaction of $4 \mathrm{~h}$ contained $0.31 \mathrm{mg} / \mathrm{ml}$ of reducing sugar. The different reducing sugar concentration of $0.31,0.62$, and $0.93 \mathrm{mg} / \mathrm{ml}$ defined as $1 \mathrm{c}, 2 \mathrm{c}$, and $3 \mathrm{c}$, respectively, were tested for prebiotic properties (Table 4). All of the experiments containing Co-CMhydrolysate showed an effect on growth of the bacterial strains tested $(p<0.05)$. The growth-enhancing activity on $L$. reuteri KUB-AC5 of 1.41-1.87 log $\mathrm{cfu} / \mathrm{ml}$ (Fig. 5) increased when the amount of Co-CMhydrolysate added to the growth medium was also increased. The experiment containing of $0.93 \mathrm{mg} / \mathrm{ml}$ of Co-CM-hydrolysate showed the highest enhancing and inhibition activity of $1.87 \mathrm{log} \mathrm{cfu} / \mathrm{ml}$ and $1.27 \mathrm{log}$ $\mathrm{cfu} / \mathrm{ml}$ against $L$. reuteri KUB-AC5 and $S$. Enteritidis S003, respectively. Interestingly, no effect on the growth of E. coli E010 could be detected. These results indicate that Co-CM-hydrolysate contains yet unidentified oligosaccharides which have a potential prebiotic property of enhancing growth of L. reuteri while apparently inhibiting growth of Salmonella Enteritidis, which are representatives of desirable lactic acid bacteria and pathogenic bacteria, respectively. To understand the growth-affecting mechanism, identification of the main oligosaccharides obtained in this hydrolysate and further studies will be needed.

\section{DISCUSSION}

Only one single mannanase protein designated mannanase S1 was detected in the culture solution of $K$. oxytoca KUB-CW2-3 when grown on a medium containing copra mannan. It is a monomeric protein of $165 \mathrm{kDa}$ with pI of 3.5 . The molecular mass of mannanase $\mathrm{S} 1$ is somewhat higher than those obtained from other microbial mannanases. Bacillus spp. mannanases have a molecular mass in the range of 37$40 \mathrm{kDa}^{20-22}$. Nevertheless, Takeda et $\mathrm{al}^{23}$ reported that the purified mannanase from Bacillus sp. strain JAMB-750 has a molecular mass of $130 \mathrm{kDa}$. Fungal mannanases, however, seem to vary more significantly in their mass. Aspergillus mannanases range from 30$110 \mathrm{kDa}^{24}$ while those of Trichoderma range from 32-46 kDa ${ }^{25,26}$.

The optimum $\mathrm{pH}$ of mannanase $\mathrm{S} 1$ was similar to those of some bacterial and fungal mannanases which are in the range of 3.0-6.0 $22,26-29$. With regard to stability of mannanase $\mathrm{S} 1$, the results obtained suggest that mannanase $\mathrm{S} 1$ is quite stable at higher temperature with half life times of several hours in the temperature range of $50-70{ }^{\circ} \mathrm{C}$.

Mannanases are glycoside hydrolases $(\mathrm{GH})$ which degrade mannans and heteromannans. Glycosides hydrolases from various sources were classified into different families based on amino acid sequences similarities and hydrophobic cluster analysis ${ }^{30}$. These enzymes have been shown to belong to either $\mathrm{GH}$ family 5 or 26 . The N-terminal sequence of mannanase S1 showed no match with the N-terminal region of any other bacterial mannanase belonging to these two families when analysed by Protein-Protein BLAST (blastp) (http://www.ncbi.nlm.nih.gov). In addition, no close similarity could be detected when aligning this $\mathrm{N}$ terminal sequence with other microbial mannanases by using the CLUSTALW program (http: //www.ebi.ac.uk/Tools/msa/clustalw2/). Family GH5 was formerly known as cellulase family A and encompasses diverse enzymes ${ }^{31}$. Amino acid sequence alignments of members of family 5 rarely presented levels of sequence identity greater than $20 \%{ }^{32}$. More- 
over, typical mannanase domain sequences of family GH5 were rather distributed throughout the entire gene. Family GH26 typically shows a short conserved region rich in aromatic amino acid, $\mathrm{WFWWG}^{33}$, which can be found in the N-terminal region but also in other parts of the protein ${ }^{34}$. The N-terminal sequence of mannanase $\mathrm{S} 1$ does not show this conserved region. Hence mannanase S1 might belong to family GH5. However, the complete protein sequence should be known for an exact classification.

Based on its rather broad substrate specificity, mannanase $\mathrm{S} 1$ can be applied for the hydrolysis of various mannans, that carry substituents to a varying degree. LBG and konjac mannan were employed as substrates for the determination of kinetic constants of the enzyme. Locust bean gum is a galactomannan consisting of a mannose backbone with galactose side groups, while konjac mannan is a glucomannan with both mannosyl and galactosyl moieties in its main chain but which is devoid of side chain substituents. The kinetic constants of mannanase S1 were rather similar for both substrates. As judged from studying the hydrolysis of LBG and the resulting reaction products, both galactose and various oligosaccharides were obtained, indicating that mannanase S1 can hydrolyse both the $\beta$-1,4-mannosidic linkage in the polymer main chain as well as the galactosyl side chain. Hydrolysis of locust bean gum by $100 \mathrm{mM} \mathrm{CoCl} 2$ treated mannanase $\mathrm{S} 1$ yielded galactose and unknown compounds which moved further than mannotriose and mannotetraose on TLC. Sugiyama et al ${ }^{35}$ reported that hydrolysis of mannan can result in various kinds of unknown oligosaccharides and unknown substances. These unknown compounds may be mannooligosaccharides carrying side chains that can result from transferase activity of the hydrolase.

In general, mannooligosaccharides (MOS) that are already available on the market are carbohydrates extracted from the outer wall of yeast cells. They are used because of their ability to reduce growth of pathogenic bacteria, such as Salmonella sp. and E. coli, in the digestive tract of animals. Few studies have found an effect of MOS to growth inhibition of Salmonella sp. Spring et al ${ }^{36}$ determined the effect of MOS on caecal fermentation parameters, caecal microflora, and enteric pathogens in chicks. Caecal $S$. Typhimurium 29E concentrations decreased from 5.40 to $4.01 \mathrm{log} \mathrm{cfu} / \mathrm{g}(P<0.05)$ after receiving $4000 \mathrm{ppm}$ dietary MOS. Moreover, $S$. Typhimuriumchallenged turkeys fed by MOS had a decreased incidence of faecal contamination, whereas broilers fed by MOS reduced faecal counts of $S$. Dublin and E. $\operatorname{coli}^{37}$. The effect of these yeast mannans and mannooligosaccharides, however, is thought to be through their binding of certain adhesion sites on these bacteria. Our study indicates a different source of MOS, those derived from copra mannan. Co-CMhydrolysate exhibited a potential growth inhibition of Salmonella Enteritidis S003 and was able to promote growth of $L$. reuteri, which is a well known probiotic organism. Typically, prebiotic properties should not only reduce growth of pathogens but must also promote growth of desirable and beneficial bacteria, such as Lactobacillus. This is the first paper dealing with MOS formation from copra mannan by using mannanase S1 from $K$. oxytoca KUB-CW2-3 and the elucidation of its prebiotic properties.

MOS are commonly used in animal feed to improve digestibility and support gastrointestinal health ${ }^{36,38,39}$. In addition, it may have a diverse prebiotic property showing an anti-obesity effect as proposed by Smith et $\mathrm{al}^{4}$. Its combination with an appropriate probiotic would lead to synbiotic application. Further studies relating to the properties of MOS, formed by mannanase S1-treated copra mannan will be carried out in the future to address some of these questions.

Acknowledgements: This work was supported by the Commission on Higher Education, the Ministry of Education, Royal Thai Government, and the ASEAN-EU University Network Programme (AUNP). Thanks to Centre of Excellence on Agricultural Biotechnology, Science and Technology Postgraduate Education and Research Development Office, Commission on Higher Education, Ministry of Education for FPLC chromatographic system support.

\section{REFERENCES}

1. Biggs P, Parsons CM (2007) The effect of several oligosaccharides on true amino acid digestibility and true metabolizable energy in cecectomized and conventional roosters. Poultry Sci 86, 1161-5.

2. Gibson GR, McCartney AL, Rastall RA (2005) Prebiotics and resistance to gastrointestinal infections. $\mathrm{Br} \mathrm{J}$ Nutr 93, S31-4.

3. Rastall RA, Gibson GR, Gill HS, Guarner F, Klaenhammer TR, Pot B, Reid G, Rowland IR, Sanders ME (2005) Modulation of the microbial ecology of the human colon by probiotics, prebiotics and synbiotics to enhance human health: an overview of enabling science and potential applications. FEMS Microbiol Ecol 52, 145-52.

4. Smith DLJ, Nagy TR, Wilson LS, Dong S, Barnes S, Allison DB (2010) The effect of mannan oligosaccharide supplementation on body weight gain and fat accrual in C57BI/6J mice. Obesity 18, 995-9.

5. Choct M (2001) Nutritional constraints to alternative ingredients. Asa Tech Bull AN31-2001, 1-9. 
6. Purwadaria T, Haryati T, Darma J, Munazat OI (1995) In vitro digestibility evaluation of fermented coconut meal using Aspergillus niger NRRL 337. Bull Animal Sci Special Edition, 375-81.

7. Braithwaite KL, Black GW, Hazlewood GP, Ali BR, Gilbert HJ (1995) A non-modular endo- $\beta$-1,4-mannanase from Pseudomonas fluorescens subspecies cellulosa. Biochem J 307, 1005-10.

8. Gübitz GM, Sachslehner A, Haltrich D (2000) Microbial mannanases: substrates, production, and application. In: Himmel ME, Baker JO, Saddler JN (eds) Glycosyl Hydrolases for Biomass Conversion. ACS Symp Ser 769, 236-62.

9. Sánchez C (2009) Lignocellulosic residues: biodegradation and bioconversion by fungi. Biotechnol Adv 27, 185-94.

10. Titapoka S, Keawsompong S, Haltrich D, Nitisinprasert S (2008) Selection and characterization of mannanaseproducing bacteria useful for the formation of prebiotic manno-oligosaccharides from copra meal. World $\mathrm{J} \mathrm{Mi}$ crobiol Biotechnol 24, 1425-33.

11. Puchart V, Vrsanska M, Sovoboda P, Pohl J, Ogel ZB, Biely P (2004) Purification and characterization of two forms of endo- $\beta$-1,4-mannanase from a thermotolerant, fungus, Aspergillus fumigatus IMI 385708 (formerly Thermomyces lanuginosus IMI 158749). Biochim Biophys Acta 1674, 239-50.

12. Talbot G, Sygusch J (1990) Purification and characterization of thermostable $\beta$-mannanase and $\alpha$-galactosidase from Bacillus stearothermophilus. Appl Environ Microbiol 56, 3505-10.

13. Zhang J, He Z, Hu K (2000) Purification and characterization of $\beta$-mannanase from Bacillus licheniformis for industrial use. Biotechnol Lett 22, 1375-8.

14. Nitisinprasert S, Nilphai V, Bunyun P, Sukyai P, Doi K, Sonomoto K (2000) Screening and identification of effective thermotolerant lactic acid bacteria producing antimicrobial activity against Escherichia coli and Salmonella sp. resistant to antibiotics. Kasetsart J (Nat Sci) 34, 387-400.

15. Mohammad ZH, Abe J, Hizukuri S (1996) Multiple forms of $\beta$-mannanase from Bacillus sp. KK01. Enzym Microb Tech 18, 95-8.

16. Miller GL (1959) Use of dinitrosalicylic acid reagent for determination of reducing sugar. Anal Chem 31, 426-8.

17. Lowry $\mathrm{OH}$, Rosembrough NJ, Farr AL, Randall PL (1951) Protein measurement with the Folin phenol reagent. J Biol Chem 193, 265-75.

18. Laemnli UK (1970) Cleavage of structural protein during the assembly of the head of bacteriophage T4. Nature 227, 680-5.

19. Sachslehner A, Foidl G, Foidl N, Gubitz G, Haltrich D (2000) Hydrolysis of isolated coffee mannan and coffee extract by mannanases of Sclerotium rolfsii. J Biotechnol 80, 127-34.

20. Jiang Z, Wei Y, Li D, Li L, Chai P, Kusakabe I (2006)
High-level production, purification and characterization of a thermostable $\beta$-mannanases from the newly isolated Bacillus subtilis WY34. Carbohydr Polymer 66, 88-96.

21. Zakaria MM, Yamamoto S, Yagi T (1998) Purification and characterization of an endo-1,4- $\beta$-mannanase from Bacillus subtilis KU-1. FEMS Microbiol Lett 158, 25-31.

22. Mendoza NS, Arai M, Kawaguchi T, Yoshida T, Joson LM (1994) Purification and properties of mannanase from Bacillus subtilis. World J Microbiol Biotechnol 10, 551-5.

23. Takeda N, Hirasawa K, Uchimura K, Nogi Y, Hatada Y, Usami R, Yoshida Y, Grant WD, Ito S, Horikoshi K (2004) Purification and enzymatic properties of a highly alkaline mannanase from alkaliphilic Bacillus sp. strain JAMB-750. J Biol Macromol 4, 67-74.

24. Regalado C, García-Almendárez BE, Venegas-Barrera LM, Téllez-Jurado A, Rodríguez-Serrano G, HuertaOchoa S, Whitaker JR (2000) Production, partial purification and properties of $\beta$-mannanases obtained by solid substrate fermentation of spent soluble coffee wastes and copra paste using Aspergillus oryzae and Aspergillus niger. J Sci Food Agr 80, 1343-50.

25. Ferreira HM, Filho EXF (2004) Purification and characterization of a $\beta$-mannanase from Trichoderma harzianum strain T4. Carbohydr Polymer 55, 401-9.

26. Arisan-Atac I, Hodits R, Kristufek D, Kubicek CP (1993) Purification, and characterization of a $\beta$-mannanase of Trichoderma reesei C-30. Appl Microbiol Biotechnol 39, 58-62.

27. Sachslehner A, Haltrich D (1999) Purification and some properties of a thermostable acidic endo- $\beta-1,4-$ D-mannanase from Sclerotium (Athelia) rolfsii. FEMS Microbiol Lett 177, 47-55.

28. Ademark P, Varga A, Medve J, Harjunpää V, Drakenberg T, Tjerneld F, Stålbrand H (1998) Softwood hemicellulose-degrading enzymes from Aspergillus niger: purification and properties of a $\beta$-mannanase. J Biotechnol 63, 199-210.

29. Gubitz GM, Hayn M, Urbanz G, Steiner W (1996) Purification and properties of an acidic $\beta$-mannanases from Sclerotium rolfsii. J Biotechnol 45, 165-72.

30. Henrissat B, Davies G (1997) Structural and sequencebased classification of glycoside hydrolases. Curr Opin Struct Biol 7, 637-44.

31. Davies G, Henrissat B (1995) Structure and mechanism of glycosyl hydrolases. Structure 3, 853-9.

32. Dhawan S, Kaur J (2007) Microbial mannanases: an overview of production and applications. Crit Rev Biotechnol 27, 197-216.

33. Zhang Q, Yan X, Zhang L, Tang W (2006) Cloning, sequences analysis, and heterologous expression of a $\beta$-mannanase gene from Bacillus subtilis Z-2. Mol Biol 40, 368-74.

34. Ethier N, Talbot G, Sygusch J (1998) Gene cloning, DNA sequencing, and expression of thermostable 
$\beta$-mannanase from Bacillus stearothermophilus. Appl Environ Microbiol 64, 4428-32.

35. Sugiyama N, Shimahara H, Andoh T, Takemoto M (1973) Konjac-mannanase from the tuber of Amorphophallus konjac C. Koch. Agr Biol Chem 37, 9-17.

36. Spring P, Wenk C, Dawson KA, Newman KE (2000) The effects of dietary mannooligosaccharides on cecal parameters and the concentration of enteric bacteria in the ceca of Salmonella-challenged broiler chicks. Poultry Sci 79, 205-11.

37. Spring P, Dawson KA, Newman KE, Wenk C (1996) Effect of MOS on different cecal parameters and on cecal concentrations of enteric bacteria in challenged broiler chicks. Poultry Sci 75(Supp. 1), Abstr. 138.

38. Naughton PJ, Mikkelsen LL, Jensen BB (2001) Effects of non-digestible oligosaccharides on Salmonella enterica serovar Typhimurium and nonpathogenic Escherichia coli in the pig small intestine in vitro. Appl Environ Microbiol 67, 3391-5.

39. Waldroup PW, Fritts CA, Yan F (2003) Utilization of bio-mos mannan oligosaccharide and bioplex copper in broiler diets. Int J Poultry Sci 2, 44-52. 